theme is the inquiry how far the form and structure of living things can be interpreted in terms of the physical forces acting within the life-time of the individual organism. It appeared at a time when increasing attention was being paid to this 'causal morphology' as distinguished from the 'historical morphology' which was the almost exclusive study of the period that preceded it. Sir D'Arcy was much too wise and experienced a naturalist to imagine that such an interpretation would take us all the way, but some of his followers were less cautious. In his second, much enlarged, edition, published in 1942, he has to add a warning; in the end, he says, "the twofold problem of accumulated inheritance, and of perfect structural adaptation, confronts us once again and passes all our understanding".

A striking testimony to the influence of this book on a younger generation of biologists is given by the volume of "Essays on Growth and Form presented to D'Arcy Wentworth Thompson", edited by Prof. W. E. Le Gros Clark and Prof. P. B. Medawar, published by the Clarendon Press in 1945.

This is not the place, even if I had the knowledge necessary, to assess the value of Sir D'Arcy's studies on the natural history of the ancient world. His "Glossary of Greek Birds" appeared in 1895, and a second edition in 1942 : his translation of Aristotle's "Historia Animalium" was published in 1910 and his "Glossary of Greek Fishes" in 1945; the repute of these and his numerous shorter papers on classical subjects may be gathered from the fact that he was president of the Classical Association in 1929 and of the Scottish Classical Association in 1935. The list of his honorary degrees, honorary memberships, lectureships, medals and so forth is far too lengthy to be given here, ranging, as it does, from Aberdeen to Johannesburg and from Boston to Delhi. He was elected to the Royal Society in 1916, was a vicepresident during 1931-33, and awarded the Darwin Medal in 1946. He was president of the Royal Society of Edinburgh during 1934-39. He flew to India at the end of 1946 as one of the four delegates sent by the Royal Society to the meeting of the Indian Science Congress in Delhi; but the strain of the journey was too much for his years and he never completely recovered his health. $\mathrm{He}_{\Theta}$ was knighted in 1937.

Sir D'Arcy was a man of very striking presence with a resonant and beautifully modulated voice which made his lectures and addresses a pleasure to listen to.

Lady Thompson and her three daughters are assured of the sympathy of his innumerable pupils and friends in all quarters of the globe.

W. T. Calman

SIR D'ARCy Thompson was not the only man of science in his generation who 'kept up his classics' and pursued them in connexion with his professional work. Other biologists were Sir Edward Poulton and Dr. F. A. Dixey. But Sir D'Arey's studies were on an ampler scale. Both his "Glossary of Greek Birds", published forty years ago and recently in a wellgroomed second edition, and his "Glossary of Greek Fishes", reviewed in these columns only a few months since, are the classical books of reference in their subject, and illustrate his wide range of literary scholarship as well as his tireless industry. They are supported by a rich flow of smaller articles and notes covering a wider field, and by invaluable services as a member of the staff of the revised "Liddell and
Scott". Two examples will illustrate his range and versatility. He was the first to make geometrical sense of Herodotus' description of the Great Pyramid, and to show how its form was related to the processes of its construction. And his knowledge was at his instant disposal. I referred to him some years ago, at the request of a distinguished surgeon, the Homeric description of the death-struggle of Nestor's chariot horse, struck through the forehead by an arrow. The reply came by return of post-" "written in the laboratory" : the arrow had grazed the cerebellum, and the convulsive movements of the limbs, causing the horse to roll over and over, were precisely what were to be expected. He had seen the same deathstruggle in a rabbit, and dissected out the fatal pellet from an identical wound.

On the low shore of Lake Superior, the train nearly left behind three of the party, plucking wild raspberries. My snapshot bears the legend, "Berries and beavers". JohN L. MYres

\section{Prof. B. E. Livingston}

WITH the passing of Burton Edward Livingston early this year, plant physiology in the United States has lost a distinguished figure. Himself an indefatigable investigator, he devoted much time and energy to the stimulation of scientific research and the promotion of co-operation and intercourse among his fellow men of science. From 1920 onwards he was a member of the executive of the American Association for the Advancement of Science, for fourteen years as secretary, and became its chairman in 1941. He served on the National Research Council. Among many other activities he took a prominent part in the foundation, in 1924, of the American Society of Plant Physiologists; he was elected one of its first vice-presidents and was the first to be elected life member under the Charles Reid Barnes Foundation. The esteem in which the Society held him as an investigator was very appropriately indicated when in 1946 it conferred on him the Stephen Hales Award, since his chosen field was the quantitative study of the water relations of plants, in which Stephen Hales was the pioneer.

Livingston's interest in this aspect of plant physiology was established at the very beginning of his career. Having graduated at Michigan in 1898, he went to Chicago as fellow and assistant in plant physiology. Five years later, at the age of twentyeight, he published his book on "The Role of Diffusion and Osmotic Pressure in Plants". A visit in the summer of 1904 to the recently established Desert Laboratory of the Carnegie Institution at Tueson, Arizona, provided the material for his "Relation of Desert Plants to Soil Moisture and to Evaporation" (1906), in which the scheme of his later work was foreshadowed. A short period with the U.S. Bureau of Soils and three years at Tucson preceded his appointment in 1909 to the chair of plant physiology at the Johns Hopkins University, which he occupied until his retirement in 1940.

Livingston's contributions were marked by comprehensive grasp and clarity of analysis. He emphasized from the first the dynamic aspect of the relations between plants and their environment. His approach was primarily that of a physiological ecologist : the influence of Schimper is evident in his early work. He was impressed by the complexity of the environment and the interaction of factors in their influence upon the plant. He held the separate measurement of 
those factors to be insufficient in the study of plant distribution and adaptation; so he sought methods of assessing their integrated effects. He introduced the dynamic concepts of the water-supplying power of the soil and the evaporating power of the air. His porous porcelain atmometers (evaporimeters) with standardized spherical bulbs have been very widely used. $\mathrm{He}_{\Theta}$ sought to measure the watersupplying power of the soil by inserting osmometers in it. Although he may have over-estimated the mobility of capillary water, his experimental approach was sound and stimulating. Connected with these investigations was his introduction of the autoirrigator, a porous pot supplying water to the soil at a predetermined capillary potential.
As physiologist he sought to express the water relations of plants in terms of quantitative physical laws, as affected by variations of water content and internal resistances as well as by external factors. As ecologist he aimed at correlating the distribution of vegetation with the quantitative data and at giving precision to otherwise vaguely defined distinctions. This is the keynote of "The Distribution of Vegetation in the United States as related to Climatic Conditions", which he published with Forrest Shreve in 1921.

The long series of papers which emanated from Baltimore during the thirty years of his tenure are ample proof of the stimulus of his leadership.

D. THODAY

\section{NEWS and VIEWS}

\section{Egyptology in the University of Liverpool:} Prof. A. M. Blackman

WIтн the retirement, on reaching the age-limit, of Dr. Aylward M. Blackman from the Brunner chair of Egyptology, which he has held since 1934, the University of Liverpool loses a fruitful teacher and a valued contributor to a number of branches of ancient Egyptian studies. Born at Norwich in 1883 , and a keen student of Egyptology from the age of sixteen, Dr. Blackman was educated first privately, then at St. Paul's School, London, and Queen's College, Oxford, where in 1906 he took a first class in Oriental Studies. During 1906-14 and 1920-21 he took part in or directed excavations and recording in Egypt (Oxyrhynchus, Abydos, Meir, El-Amarnah) and the Sudan (Survey of Nubia, Buhen, Faras, Sesebi). During 1912-18 he was Laycock Student of Egyptology of Worcester College, Oxford. Since 1935 he has been joint editor, with Prof. J. P. Droop, of the Annals of Archoeology and Anthropology, and during 1922-35 was a member of the Council of the Royal Asiatic Society. From 1936 on he has been special lecturer in Egyptology in the University of Manchester. His publications have been numerous ; chief among them are four volumes on "The Rock Tombs of Meir" (1914-24), with about eighty plates drawn by himself, and volumes on the Lower Nubian temples of Dendûr, Derr and Bîgeh. Other works deal especially with Egyptian myth and ritual. $\mathrm{He}$ has done much to present Ancient Egypt to a wide public. All Egyptologists will hope that it will be possible for Dr. Blackman to continue his Egyptological researches for many years to come.

Mr. H. W. Fairman

Dr. Blackman's successor is Mr. Herbert Walter Fairman, who has been an active worker in the field since 1929 (war-service excepted). Mr. Fairman was born at Clare, Suffolk, in 1907; but he spent his early years in Egypt, where his father was a mission. ary. He was educated at Goudhurst School, Kent, going eventually to the University of Liverpool, where he studied Egyptology under the late Prof. Peet. For the next ten years he took part in excavations conducted in Egypt and the Sudan by the Egypt Exploration Society-at the cemetery of the Buchis bulls at Armant, 1929-31 ; at El-Amarnah, 1930-36 ; at Sesebi, 1936-38; at Amarah West, 1938-39 and 1947-48. In 1937 he became the Society's field director. At Armant and El-Amarnah he was primarily responsible for the publication of the inscriptions. The need to interpret the difficult late writing of the Ptolemaic and Roman inscriptions relating to the Buchis bulls led him to specialize in the texts of those periods, and he has become one of the very few contemporary authorities on them. During 1940-47 he was engaged in war-time duties at the British Embassy, Cairo, and while there he gave many lectures on Ancient Egypt to troops in his spare time. It is hoped that his teaching duties at Liverpool will leave him opportunities to continue his researches into the texts of the latest periods, which contain many remarkable matters not generally known even to Egyptologists.

\section{Chemistry at the University College of North Wales, Bangor: Dr. Stanley Peat, F.R.S.}

Dr. Stanley Peat, reader in organic chemistry in the University of Birmingham, has been elected to the chair of chemistry at the University College of North Wales, Bangor, University of Wales, in succession to Prof. E. D. Hughes, who is going to University College, London (Nature, April 3, p. 511). Dr. Peat had a distinguished career as a student of King's College, Newcastle, University of Durham, which he entered with a State Scholarship and the Earl Grey Scholarship in 1921. He graduated with first-class honours in the University of Durham in 1924 and was awarded the Saville Shaw and the Freire-Marreco Medals on graduation. He there joined the research school of Sir Norman Haworth, and eventually followed him to the University of Birmingham. His first joint publication in 1926 was on a revision of the structural formula of glucose. After obtaining his doctorate he was appointed lecturer in the Department of Physiology in the Medical School of Birmingham under Prof. I. de Burgh Daly, and published several papers in physiological journals on histamine. In 1934 he transferred to the teaching staff of the Department of Chemistry at Birmingham and engaged in constitutional studies of the polysaccharides. Outstanding among his pub. lications are: his proof by synthesis of the configuration of glucosamine, the constitution of maltose, the studies of the mechanism of inversion of configuration in the sugar group, and especially the study of the enzyme systems responsible for the synthesis and degradation of starch. This latter work has led to the isolation of the $Q$-enzyme which is responsible for the biosynthesis in the presence of 